\title{
Assessment of the Aquatic Plant Community in JaCkson Lake, Grand Teton National PaRK, WYOMING: 1991 STATUS REPORT
}

\author{
CAROL BREWER $\downarrow$ DEPARTMENT OF BOTANY \\ UNIVERSITY OF WYOMING $\downarrow$ LARAMIE
}

\section{$\checkmark \quad$ INTRODUCTION}

Since the construction of the first dam at the Snake River outlet at Jackson Lake in the early 1900 's, the littoral habitat has been subjected to numerous perturbations of varying intensities. Changing water levels, a consequence of reservoir drawdown schedules, alter plant community species composition and distribution over time. From the perspective of a plant, water level changes present a challenge to growth and community persistence. A plant which begins the growing season $2 \mathrm{~m}$ deep may be under $4 \mathrm{~m}$ of water after spring runoff fills the reservoir. Later in the summer, the same plant may be left at a depth of only $1 \mathrm{~m}$ as water is removed from the reservoir during summer drawdown.

The magnitude and timing of water level fluctuations may be one of the most important factors regulating macrophyte community processes upslope on the vertical gradient in Jackson Lake (Brewer and Parker 1990). Under normal regulation, annual changes of 3-4 m are sufficient to select for a plant community with a typically weedy phenology (e.g., Elodea canadensis). In natural lakes with substantially lower annual changes in water levels, species that produce seeds annually are favored (e.g., Potamogeton species). Moreover, drawdowns greater than several meters substantially reduce the lake bed area suitable for the development of extensive shallow water plant beds.
The most recent perturbations to the littoral habitat in Jackson Lake began in 1978, when the water level was lowered first from $2065 \mathrm{~m}$ (normal pool) to somewhere between $2060-2062 \mathrm{~m}$. Then in 1985, the surface elevation of Jackson Lake was further lowered to $2057 \mathrm{~m}$ to facilitate repair and modification of the Jackson Lake dam. The entire lake bed was seriously impacted during the four years that the dam was being restored. While the lake bed in the borrow zone and the area adjacent to the dam were obviously impacted by repair activities, the entire shallow littoral zone was severely perturbed when previously inundated sediments were exposed for four years. In 1989, repair was completed and the reservoir was allowed to fill back to the normal pool elevation of $2065 \mathrm{~m}$.

Because of severe impacts to the littoral habitat and significant reduction of the submergent plant community caused by restoration of the dam, the status of the aquatic plant community was monitored during the summers of 1989-1991. This report summarizes the status of the aquatic plant community three years after repair of the dam was completed.

\section{SUMMARY OF LAKE CONDITIONS IN 1991}

\section{Photic Zone}

In general, the bottom limit of the photic zone was deeper in August 1991, compared to previous 


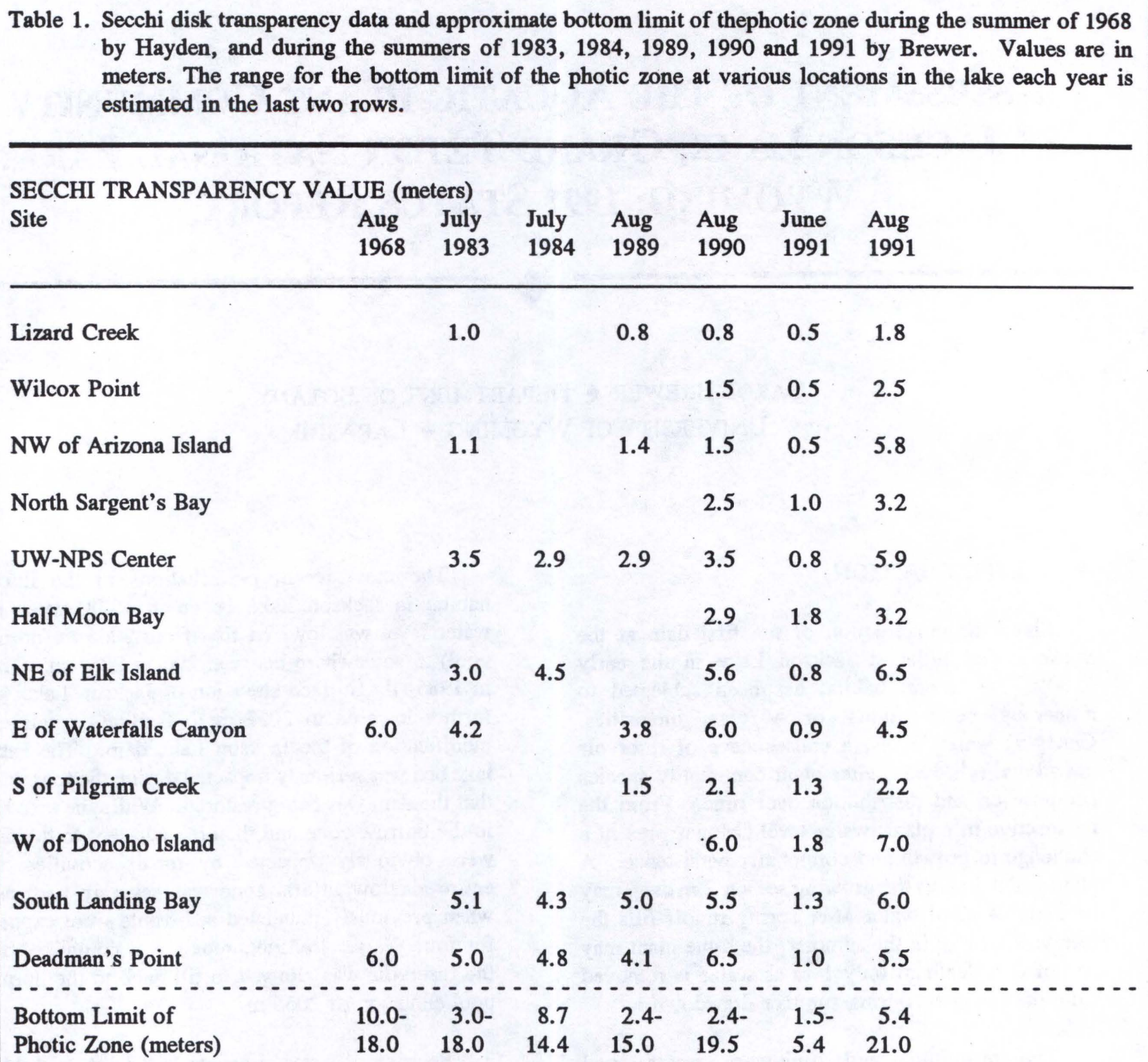

years for most locations in the lake (Table 1). The bottom limit of the photic zone was still less than 2.5 meters in shallow water in both the northern part of the lake and in the Hermitage Point and Donoho Island areas. Low transparency values are attributed to increased suspended sediments in shallow areas due to high water movement during severe August thunderstorms.

\section{$\underline{\text { Lake Bed Sediments }}$}

Sediment composition is much the same as described in 1986. The film of fine silts which covered all sediments at the study sites in 1989 seems to have settled and is not easily mobilized by disturbance.

\section{Community Composition}

In 1991, nineteen rooted species were collected from Jackson Lake (Table 2). This value is higher than the value for 1989 when only eight species were collected. One new species, Fontinalis sp., a small aquatic moss, was collected for the first time in 
Table 2. Names of families and species collected from Jackson Lake in 1968 by Hayden, reported by Brewer in 1986, and collected by Brewer in 1989, 1990 and 1991. + indicates present, - indicates not reported, and ? indicates that the species may have been present but positive identification was not possible based on the plant material collected.

Family and

Species

Years reported in collections

$\begin{array}{lllll}1968 & 1986 & 1989 & 1990 & 1991\end{array}$

\section{Characeae}

Chara sp.

Nitella sp.

Fontinalaceae

Fontinalis sp.

Alismatacea

Sagittaria cuneata Shel.

Callitrichaceae

Callitriche sp.

Ceratophyllaceae

Ceratophyllum demersum L.

Cyperaceae

Eleocharis acicularis (L.)R.\&S.

Haloragaceae

Myriophyllum sibiricum Kom.

Myriophyllum spicatum L.

Hippuridaceae

Hippuris vulgaris L.

Hydrocharitaceae

Elodea canadensis Michx.

Polygonaceae

Polygonum amphibium var. stipulaceum

Coleman

Potamogetonaceae

Potamogeton alpinus Balb.

Potamogeton filiformis Pers.

Potamogeton gramineus L.

Potamogeton pectinatus L.

Potamogeton pusillus L.

Potamogeton richardsonii (A. Benn)

Rydberg

Potamogeton sp.

\section{NONVASCULAR AQUATIC MACROPHYTES}

CHAROPHYCEAE (Macrophytic green algae)

\section{VASCULAR AQUATIC MACROPHYTES TRACHEOPHYTA}

MUSCI (Aquatic mosses)

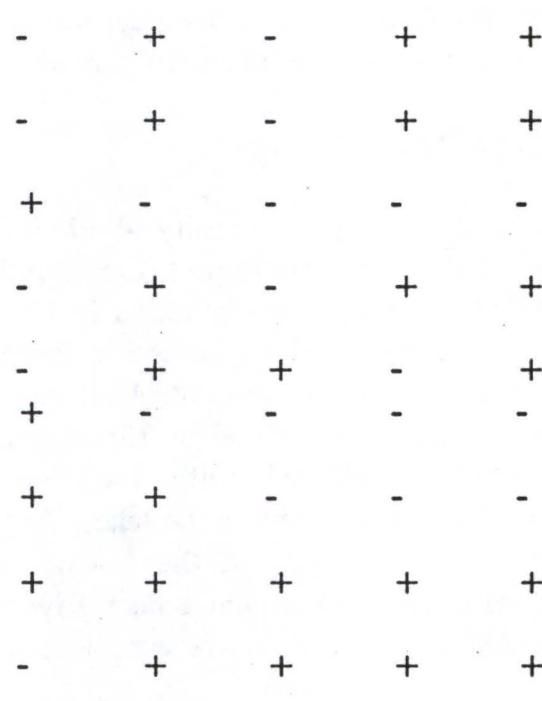

$\begin{array}{llll}- & + & - & -\end{array}$

$+\quad-\quad$ ?

$\begin{array}{lllll}- & + & - & & \end{array}$

- + t +

$\begin{array}{llll}- & + & - & +\end{array}$

$+\quad+\quad-\quad+$

$-+\quad+\quad+$ 
Table 2. Continued

Family and

Species

Years reported in collections

$\begin{array}{lllll}1968 & 1986 & 1989 & 1990 & 1991\end{array}$

Ranunculaceae

Ranunculus aquatilis var. capillaceus

(Thuill.)DC

Ranunculus flamula L.

Scrophulariaceae

Limosella aquatica $\mathrm{L}$.

Sparganiaceae

Sparganium sp.

Zannichelliaceae

Zannichellia palustris $\mathrm{L}$.

Total species reported

$\begin{array}{lllll}+ & + & + & + & + \\ - & + & - & ? & + \\ - & - & - & + & + \\ - & + & + & + & + \\ - & + & - & + & + \\ 8 & 21 & 8 & 13 & 19\end{array}$

Jackson Lake in 1991. This species was found in 1.5 - $3 \mathrm{~m}$ of water in the northern part of the lake.

\section{Community Distribution}

In general, plant density was low in the photic zone. On exposed shorelines, the littoral habitat was still devoid of aquatic vegetation in 1991. On most of the shallow marshy lake bed in the north part of the lake, decaying willows were still present. Blooms of a filamentous green algae (Spirogyra sp.), were commonly associated with the dead terrestrial vegetation that remains in the lake. At Wilcox Bay, near Arizona Island, in the borrow area, North Sargent's Bay and at the Snake River outlet near Lizard Creek, algae blooms were locally prominent.

By August 1991, the distribution of plants had spread considerably compared to 1989 and 1990 , especially in bays. Dense submersed plant beds were present in North Sargent's Bay, the southern most end of Spaulding and Half Moon Bays', and the south and west shores of Moran Bay. Sargent's Bay and South Landing Bay were exceptions. Plant density was low in Sargent's Bay and there was no evidence of rooted macrophytes in South Landing Bay.

Parts of the northern shallow zone (the area of the shoreline extending from Arizona Island to the northern most part of the lake and then south to
Wilcox Point) were planted in 1990 with Elodea canadensis and Potamogeton pectinatus. Unfortunately, there was an extensive bloom of Spirogyra sp. and planted material did not survive into 1991. Natural revegetation, though slow because of high turbidity and low water clarity, has finally started in this region of the lake. Ultimately, the development of a stable aquatic plant community in this area will benefit wildlife and be instrumental for reducing turbidity as particulate material settles out in plant beds. These areas are normally in shallow water and it will be important that the lake level not be drawn down so low that these beds desiccate and die.

\section{REVEGETATION EFFORT}

Potamogeton pectinatus and Elodea canadensis planted by the Bureau of Reclamation have been important in the development of plant beds in the Hermitage area and North Sargent's Bay. In addition, these assisted plantings most likely provided propagule materials which have been important for establishing new beds at other locations in the lake. However, the successful development of macrophyte beds in the many new areas identified during the summer of 1991 was facilitated by the unusually stable water levels. In past summers (e.g., 1983), water level fluctuations ranged from a low surface elevation in June of $2060 \mathrm{~m}$, to a high surface 
elevation in July of $2063 \mathrm{~m}$ (unpublished data from the Bureau of Reclamation Pacific Northwest Regional Office). By September 1983, at peak macrophyte standing crop, the surface elevation was lowered to $2060 \mathrm{~m}$. Therefore, water level fluctuations were more than $3 \mathrm{~m}$ in 1983. During the summer of 1991 however, the surface elevation only varied from $2063 \mathrm{~m}$ in June, to $2064 \mathrm{~m}$ in July at peak runoff, and then down to $2062 \mathrm{~m}$ in mid-October. For most of the growing season the surface elevation was greater than $2063 \mathrm{~m}$ in 1991, a change of only $1 \mathrm{~m}$. Consequently, stable water levels coupled with good water clarity in many habitats around the lake resulted in better than expected recovery of the submergent plant community in 1991.

Assisted revegetation was locally successful in Jackson Lake. This was especially true in shallow, sheltered bays where substrates were stable, and light penetration was high by midsummer. Substrate texture may have been important in the success or failure of plantings. Sites with high success, e.g., North Sargent's Bay and Pilgrim Creek, had relatively fine grained substrates such as silts mixed with sands. Plantings were not successful in Half Moon Bay directly west of the inlet to Heron Pond where the sediments were more coarse and hard-packed. Moreover, plantings were not successful in areas such as Wilcox Point where there was an extensive filamentous algal bloom. In the future, it may be possible to select more appropriate sites for assisted revegetation based on our experience at Jackson Lake. While the recovery of the submergent plant community was slightly accelerated by the replanting effort, it would seem that natural revegetation processes are far more important for recovery of an aquatic plant community in a large water body like Jackson Lake. Replanting efforts of the magnitude executed at Jackson Lake are probably more effective in smaller water bodies.

\section{ACKNOWLEDGMENTS}

This study was funded by the Bureau of Reclamation with coordination through the Wyoming Game and Fish Department and the U.S. Fish and Wildlife Service. The field assistance of Tom Thompson (Wyoming Game and Fish Department) and the staff at the UW-NPS Research Station are gratefully acknowledged. The efforts of Steve Torbit, Art Anderson and Steve Odden from the U.S. Fish and Wildlife Service, and Tom Collins and Larry Gabriele from the Wyoming Game and Fish Department are appreciated.

\section{LITERATURE CITED}

Brewer, C.A. 1986. An investigation of the aquatic macrophyte community in Jackson Lake, Wyoming: distribution, effect of moving water, and species-specific tensile properties. M.S. thesis - University of Wyoming (unpublished).

Brewer, C.A. and M. Parker. 1990. Adaptations of macrophytes to life in moving water: upslope limits and mechanical properties of stems. Hydrobiologia 194:133-142.

Hayden, P.S. 1969. Jackson Lake limnological investigations. National Park Service Progress Report 1968-1969 (unpublished). 